\title{
RELATION OF VASCULAR HEAT EXCHANGE TO TEMPERATURE REGULATION IN THE TESTIS OF THE RAM
}

\author{
G. M. H. WAITES AND G. R. MOULE \\ C.S.I.R.O., Division of Animal Physiology, The Ian Clunies \\ Ross Animal Research Laboratory, Prospect, N.S.W., Australia*
}

(Received 14th November 1960)

\begin{abstract}
Summary. The blood flowing through the internal spermatic artery of the ram has been shown to cool by $5.2^{\circ} \mathrm{C}$ (range $4.5^{\circ}$ to $5.8^{\circ} \mathrm{C}$ ) between the aorta and the dorsal pole of the testis when testicular temperatures are $33.3^{\circ}$ to $34.7^{\circ} \mathrm{C}$. Most of the cooling occurs in the coiled portion of the artery in the spermatic cord where the venous blood returning from the testis through the pampiniform plexus warms by a similar amount. It is concluded that the vascular arrangement in the spermatic cord of the ram is a remarkably efficient heat-exchange system.

The temperature deep in the testis remained close to that of the inside of the scrotal skin throughout controlled variations in the range $28^{\circ}$ to $40^{\circ} \mathrm{C}$. Changes in the temperature of the scrotum are quickly transferred to the blood in the superficial veins of the testis which then, by heat exchange in the spermatic cord, alters the temperature of the testicular arterial inflow. It is concluded that the vascular mechanism is not by itself regulatory but it rapidly transfers any benefit of scrotal thermoregulation to all parts of the testis.
\end{abstract}

\section{INTRODUCTION}

The testes of most mammals are carried in the scrotum where they are kept cooler than the body cavity. Harrison \& Weiner (1949) suggested that the arterial blood entering the testis was pre-cooled by heat exchange with the cooler venous blood returning through the pampiniform plexus and proposed that this mechanism has a thermo-regulatory function for the testis. The blood supply to the testis of the ram flows through an extremely long internal spermatic artery and the scrotum is well developed. The relative importance of the two structures for thermo-regulation of the testis in this species is still unknown.

The present experiments were done to determine the magnitude of the temperature gradients in the blood vessels in the spermatic cord of the ram, and to find out whether a heat-exchange mechanism actively regulates the temperature of the testis, or is a passive consequence of the temperature of the scrotum.

* Postal address: The Ian Clunies Ross Animal Research Laboratory, P.O. Box 144, Parramatta, N.S.W., Australia. 


\section{MATERIALS AND METHODS}

ANIMALS AND APPARATUS

Eight Merino rams, 2 to 7 years old, were used. Thermocouples were made by spot-welding 38 and 45 s.w.G. copper and 'constantan' (copper-nickel alloy) together. They were mounted in the tips of hypodermic needles, 0.7 to $0.9 \mathrm{~mm}$ (22 and 20 s.w.G.) and $0.45 \mathrm{~mm}$ (26 s.w.G.) external diameter, respectively; tissue temperatures were recorded with the larger needle thermocouples and intravascular and skin surface temperatures with the small needle thermocouples, previously siliconed. Rectal temperatures were measured at a depth of $10 \mathrm{~cm}$ by a $38 \mathrm{s.w.G}$. thermocouple at the tip of a polythene tube filled with 'Araldite' (Ciba). Aortic temperatures were recorded upstream from the origin of the internal spermatic arteries with a 45 s.w.G. thermocouple in a siliconed polythene catheter of $0.4 \mathrm{~mm}$ external diameter.

The polythene-covered reference junctions were immersed in water at $49.20^{\circ} \pm 0.05^{\circ} \mathrm{C}$ in a thermostatically controlled container (Sunvic Controls Ltd). A 16-point potentiometric recorder (Leeds and Northrup, Type G Model S; $1 \mathrm{mV}$ full-scale deflection; e.m.f. from every thermocouple recorded once per minute) was used to measure all except air temperatures. Before the experiments, all thermocouples were calibrated in a continuously stirred water bath against a standard mercury-in-glass thermometer. Calibration and tests made between and during the experiments established an accuracy of within $0 \cdot 1{ }^{\circ} \mathrm{C}$. Air temperatures were recorded about $5 \mathrm{~cm}$ from the scrotum with a standard mercury-in-glass thermometer, and laboratory air temperatures with a sling psychrometer.

\section{EXPERIMENTAL PROCEDURE}

The procedure adopted was: (1) to record rectal, testicular and scrotal temperatures from conscious rams and then, after anaesthetizing the same animals, to record the corresponding intravascular gradients which could not otherwise be obtained; (2) to vary the temperature of the scrotum so that responses by the testicular temperatures to warming and cooling within the range $40^{\circ}$ to $28^{\circ} \mathrm{C}$ could be followed.

With the ram standing quietly in the laboratory, temperatures were recorded from the rectum, the deep testicular tissue, the subcutaneous tissue of the midposterior region of the scrotum, and from the surface of the skin overlying the subcutaneous thermocouple. The surface temperature was obtained by holding the tip of a fine needle thermocouple against the skin; such records varied within $\pm 0.25^{\circ} \mathrm{C}$. Stable temperatures were recorded for at least $10 \mathrm{~min}$. The thermocouples were removed and the ram was anaesthetized with an intravenous injection of pentobarbitone sodium B.P.; subsequent doses were given through an indwelling polythene catheter in a jugular vein.

With the animal on its side and one hind limb raised, the scrotum was supported horizontally on a wide-mesh wire platform. In seven experiments, the aortic thermocouple was passed through a hypodermic needle inserted into a femoral artery at the origin of the saphenous artery, until the tip was judged to be in the aorta. Thermocouples were inserted into some or all of the following 
blood vessels (for details for each experiment, see Table 2): an internal spermatic vein and the internal spermatic artery at the external inguinal ring (Level A, Pl. 2, Fig. 2); the internal spermatic artery on the posterior testis surface (Level B, Pl. 2, Fig. 2), or a terminal coil of the artery in the spermatic cord. Insertions at Level A were made through an incision in the anterior scrotal skin; insertions at Level B were made through paramedial incisions in the posterior scrotal skin. The tips of the needle thermocouples were approximately $1 \mathrm{~cm}$ upstream in the arteries and $1 \mathrm{~cm}$ downstream in the veins from the points of insertion, which were usually beneath intact skin to one side of the incision. The skin was closed with sutures around the polythene-covered thermocouple wires.

Rectal and deep-testicular temperatures were recorded in all experiments, and subcutaneous temperature over the mid-posterior surface of the testis was recorded in all except Ram 1. The following tissue temperatures were recorded in some experiments: cremaster muscle at the level of the dorsal pole of the testis; the surface of the tunica albuginea over the internal spermatic artery at Level B by resting a 38 s.w.G. needle thermocouple against it.

The testicular temperatures first recorded after anaesthesia in Rams 1 to 5 were higher than before anaesthesia because room air temperatures were uncontrolled and rose from $21^{\circ}$ or $22^{\circ} \mathrm{C}$ to $25^{\circ} \mathrm{C}$ during the surgery. The experiments on Rams 6 to 8 were done in an air-conditioned room at $18^{\circ} \pm 2^{\circ} \mathrm{C}$ and little change in testicular temperature occurred during the surgery. The preanaesthesia testicular temperatures were restored by circulating room air around the scrotum and stable temperatures were recorded. Testicular temperatures were then raised to $37^{\circ}$ to $40^{\circ} \mathrm{C}$ in all experiments by circulating warmed air around the scrotum. Stable temperatures were again recorded and, following this, testicular temperatures were once more reduced to the preanaesthesia range as described. Finally, the scrotum was warmed in Rams 1 to 5 (Text-fig. 1) but in Rams 6 to 8 testicular temperatures were further cooled to $28^{\circ}$ to $30^{\circ} \mathrm{C}$ (Text-figs. 2 and 3 ). The cooling rate of the testes was controlled at approximately $2^{\circ}$ to $3^{\circ} \mathrm{C} / \mathrm{hr}$ by varying the speed of the fan and its distance from the scrotum and, when necessary, by wetting the scrotal skin. The position of the tip of the scrotum was marked in two experiments so that the time could be observed when the tunica dartos muscle started to contract. In Rams 6 to 8, the skin over the spermatic cord was covered with cotton wool to minimize direct cooling of the pampiniform plexus at the lower temperatures. Temperatures were recorded continuously for 5 to $8 \mathrm{hr}$. At the end of this period, the position of the intravascular thermocouples and the patency of the vessels were confirmed. Where either was in doubt, the record was discarded. The animals were then killed and the exact position of the aortic thermocouple was determined; in five experiments, it was within $3 \mathrm{~cm}$ of the origin of the internal spermatic arteries; in Rams 4 and 2 it was 8 and $11 \mathrm{~cm}$, respectively, upstream from this point.

Blood was washed from the internal spermatic arteries by injecting warm $0.9 \%$ sodium-chloride solution through a hypodermic needle inserted at their origin from the aorta. Neoprene latex (Boston B.B. Co, Ltd) was then injected into both arteries down to Level $B$. The testes were removed and weighed. The 
length of the internal spermatic artery was measured from the latex casts obtained after removing the soft tissue with hot concentrated potassiumhydroxide solution.

\section{ANATOMICAL NOTE}

The testicular blood vessels of many species have been fully described by Harrison (1949) but the following details for the ram are relevant to this study. The straight internal spermatic artery leaves the abdomen through the inguinal canal and then coils in the spermatic cord. The convoluted portion of the artery in the cord is 1 to $4 \mathrm{~m}$ long in Merino rams (Waites \& Moule, 1960) and the coils are arranged to form a vascular cone (Pl. 2, Fig. 2). Where it emerges from the spermatic cord, the artery passes on to the posterior surface of the testis and undulates to the ventral pole. The branches which then arise wind

TABLE 1 RECTAL, TESTIGULAR AND SGROTAL TEMPERATURES $\left({ }^{\circ} \mathrm{C}\right)$
RECORDED IN EIGHT CONSGIOUS RAMS

\begin{tabular}{|c|c|c|c|c|c|c|c|}
\hline \multirow{2}{*}{$\begin{array}{l}\text { Ram } \\
\text { No. }\end{array}$} & \multirow{2}{*}{$\underset{\text { (years) }}{\text { Age }}$} & \multirow{2}{*}{ Rectal } & \multirow{2}{*}{ Testis } & \multicolumn{2}{|c|}{ Mid-posterior scrotum } & \multirow{2}{*}{$\begin{array}{c}\text { Rectal- } \\
\text { testis } \\
\text { diff. }\end{array}$} & \multirow{2}{*}{$\begin{array}{l}\text { Artery: } \\
\text { aorta- } \\
\text { testis } \\
(\mathrm{cm})\end{array}$} \\
\hline & & & & $\begin{array}{l}\text { Subcu- } \\
\text { taneous }\end{array}$ & Surface & & \\
\hline I & 3 & 39.7 & & - & - & 5.9 & 217 \\
\hline $\begin{array}{l}2 \\
3 \\
4 \\
5 \\
6 \\
7 \\
8\end{array}$ & $\begin{array}{l}7 \\
7 \\
3 \\
3 \\
5 \\
2 \\
2\end{array}$ & $\begin{array}{l}39.4 \\
39.7 \\
40.4 \\
39.4 \\
39.9 \\
40 \cdot 2 \\
39.9\end{array}$ & $\begin{array}{l}\text { Rt } 34 \cdot 0 \\
\text { Lt } 33 \cdot 9 \\
\text { Rt } 33 \cdot 8 \\
\text { Lt } 34 \cdot 6 \\
\text { Rt } 34 \cdot 5 \\
\text { Lt } 34 \cdot 2 \\
\text { Rt } 34 \cdot 7 \\
\text { Lt } 34.5\end{array}$ & $\begin{array}{l}33 \cdot 3 \\
33 \cdot 2 \\
34 \cdot 4 \\
34 \cdot 0 \\
32 \cdot 6 \\
33 \cdot 6 \\
32 \cdot 9\end{array}$ & $\begin{array}{l}31 \cdot 7 \\
31 \cdot 3 \\
33 \cdot 3 \\
33 \cdot 4 \\
32 \cdot 5 \\
31 \cdot 1 \\
31 \cdot 7\end{array}$ & $\begin{array}{l}5 \cdot 7 \\
5 \cdot 5 \\
5 \cdot 9 \\
5 \cdot 8 \\
4 \cdot 9 \\
5 \cdot 7 \\
5 \cdot 5 \\
5 \cdot 4\end{array}$ & $\begin{array}{l}215 \\
195 \\
324 \\
183 \\
199 \\
309 \\
156 \\
151\end{array}$ \\
\hline \multicolumn{2}{|c|}{ Mean } & $39 \cdot 8$ & 34.2 & 33.4 & $32 \cdot 1$ & $5 \cdot 6$ & 217 \\
\hline
\end{tabular}

Artery: internal spermatic artery length between aorta and Level B (P1. 2, Fig. 2).

Each temperature is the mean recorded from one thermocouple for not less than $10 \mathrm{~min}$.

Air temperatures were $21^{\circ} \pm 4^{\circ} \mathrm{C}$.

beneath the tunica albuginea before passing into the testicular tissue. The veins draining the testis are straight and pass over its surface to the dorsal pole. Here they join to form a profusely branching network of fine veins called the pampiniform plexus, which closely surrounds every arterial coil in the spermatic cord (Pl. 1, Fig. 1). The plexus drains into several anastomosing internal spermatic veins, which surround the straight portion of the artery almost to its origin from the aorta.

\section{RESULTS}

\section{TEMPERATURE GRADIENTS BETWEEN THE BODY AND THE TESTIS}

The rectal, testicular and scrotal temperatures recorded from eight rams standing quietly are given in Table 1 . It can be seen that the rectal-testis 


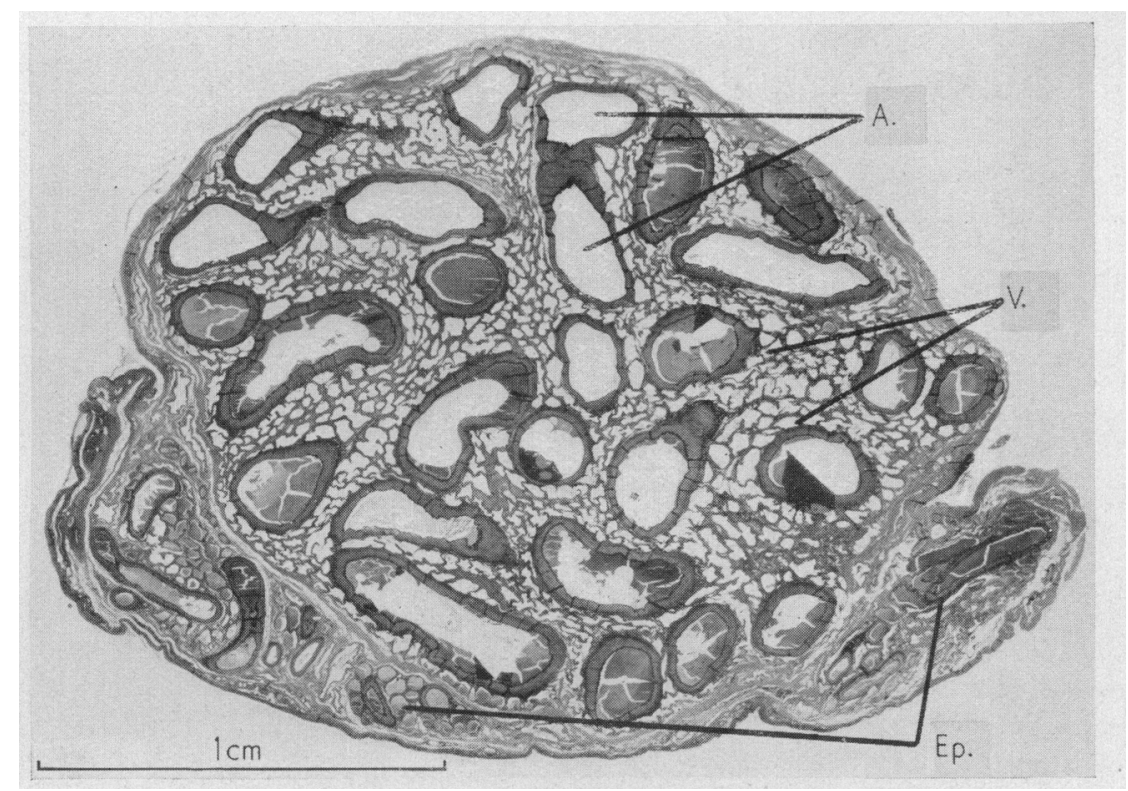

FIG. 1. Photomicrograph of a transverse section through the terminal coils of the internal spermatic artery and the pampiniform plexus of a ram. $\times 4$.

Note the single artery (A.) cut in several places and the venous plexus (V.) closely surrounding the artery. The epididymal vessels (Ep.) show a similar relationship. (Verhoeff and Van Gieson). 
PLATE 2

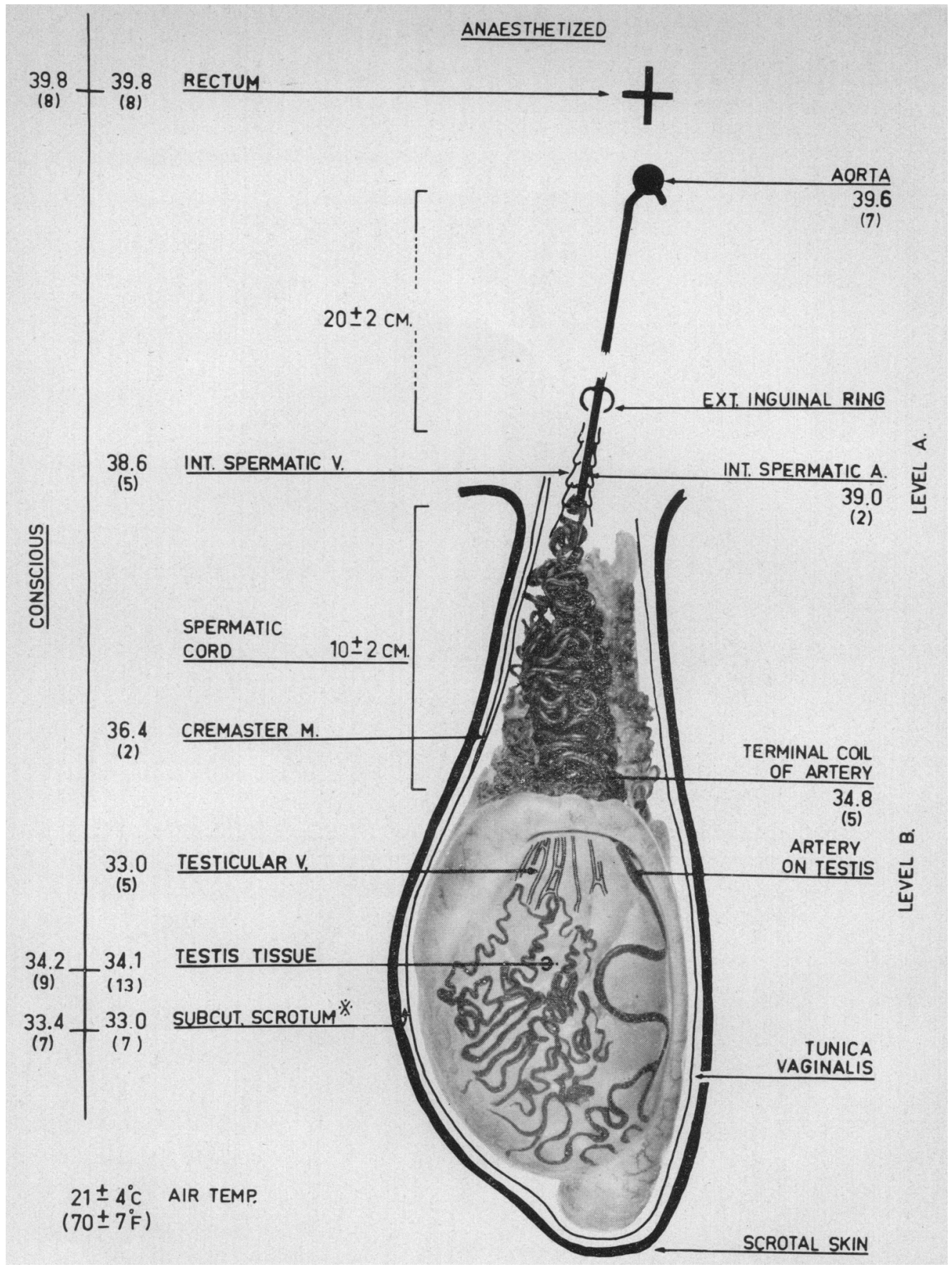

FIG. 2. Sites of measurements and comparisons of the temperatures recorded from conscious and anaesthetized rams. Lateral aspect. The internal spermatic artery has been filled with Neoprene and the cast has been exposed by removal of the pampiniform plexus and the tunica albuginea over the artery on the testis. Figures in parentheses give the number of temperatures from which the average was obtained (see Tables 1 and 2).

* Subcutaneous scrotum measurements were made beneath the posterior skin and not the anterior as shown here for the purposes of illustration only.

(Facing p. 217) 
temperature differences were very similar but that there was considerable variation in the length of the artery supplying each testis. After the same rams were anaesthetized and the thermocouples re-inserted, the testicular temperatures were restored (see Methods) to within $0.7^{\circ} \mathrm{C}$ of the pre-anaesthetic levels (compare Tables 1 and 2). The temperature gradients that were then recorded in thirteen testes are given in Table 2 and are summarized in Pl. 2, Fig. 2.

TABLE 2

\begin{tabular}{|c|c|c|c|c|c|c|c|c|}
\hline \multirow[b]{2}{*}{$\begin{array}{l}\text { Ram } \\
\mathcal{N}_{0 .} .\end{array}$} & \multirow[b]{2}{*}{ Rectal } & \multirow[b]{2}{*}{ Testis* } & \multirow{2}{*}{$\begin{array}{c}\text { Scrotum } \\
\text { mid- } \\
\text { posterior } \\
\text { subcu- } \\
\text { taneous }\end{array}$} & \multirow[b]{2}{*}{ Aorta } & \multicolumn{2}{|c|}{$\begin{array}{c}\text { Internal } \\
\text { spermatic artery }\end{array}$} & \multicolumn{2}{|c|}{$\begin{array}{c}\text { Internal } \\
\text { spermatic vein }\end{array}$} \\
\hline & & & & & Level $A$ & Level B & Level $A$ & Level $B$ \\
\hline 1 & 39.0 & Lt $34 \cdot 5$ & - & $(39.0)+$ & $38 \cdot 5$ & - & 38.0 & - \\
\hline 2 & $39 \cdot 2$ & $\begin{array}{l}\text { Rt } 34 \cdot 5 \\
\text { Rt } 33 \cdot 4 \\
\text { Lt } 33 \cdot 3\end{array}$ & $\overrightarrow{32 \cdot 3}$ & 38.7 & - & $\begin{array}{l}34.9 \ddagger \\
34 \cdot 2 \\
33.4\end{array}$ & $\frac{-}{38 \cdot 1}$ & $\begin{array}{l}31 \cdot 6 \\
- \\
32 \cdot 9\end{array}$ \\
\hline 3 & $39 \cdot 4$ & $\begin{array}{l}\text { Rt } 33.2 \\
\text { Lt } 33.9\end{array}$ & $\begin{array}{l}32 \cdot 8 \\
33 \cdot 5\end{array}$ & $39 \cdot 2$ & $3 \overline{9} \cdot 4$ & $\begin{array}{l}34 \cdot 1 \ddagger \\
34 \cdot 3 \ddagger\end{array}$ & $3 \overline{39 \cdot 5}$ & - \\
\hline 4 & 40.6 & $\begin{array}{l}\text { Rt } 34 \cdot 8 \\
\text { Lt } 34 \cdot 0\end{array}$ & $\begin{array}{l}31 \cdot 9 \\
33 \cdot 6\end{array}$ & $40 \cdot 2$ & - & $\begin{array}{l}35 \cdot 5 \ddagger \\
34 \cdot 3\end{array}$ & $38 \cdot 4$ & $\begin{array}{l}32.9 \\
33.8\end{array}$ \\
\hline & 39.7 & $\begin{array}{l}\text { Rt } 34 \cdot 8 \\
\text { Lt } 34 \cdot 0\end{array}$ & I & 357 & - & $\begin{array}{l}35 \cdot 3 \ddagger \\
34 \cdot 5\end{array}$ & - & - \\
\hline $\begin{array}{l}7 \\
8\end{array}$ & $\begin{array}{l}40 \cdot 5 \\
39 \cdot 8\end{array}$ & $\begin{array}{l}\text { Rt } 34 \cdot 2 \\
\text { Rt } 34 \cdot 7 \\
\text { Lt } 33 \cdot 9\end{array}$ & $\begin{array}{c}33 \cdot 3 \\
33 \cdot 4 \\
-\end{array}$ & $\begin{array}{l}40 \cdot 3 \\
39.7\end{array}$ & - & $\begin{array}{l}34 \cdot 8 \\
35 \cdot 2 \\
34 \cdot 4\end{array}$ & $\begin{array}{l}38 \cdot 9 \\
- \\
-\end{array}$ & $\begin{array}{c}33 \cdot 5 \\
- \\
-\end{array}$ \\
\hline Mean & 39.8 & $34 \cdot 1$ & 33.0 & $39 \cdot 6$ & $39 \cdot 0$ & $\begin{array}{l}34 \cdot 4 \\
34 \cdot 8 \downarrow\end{array}$ & $38 \cdot 6$ & 33.0 \\
\hline
\end{tabular}

* Testicular temperatures were adjusted to within $0.7^{\circ} \mathrm{C}$ of those recorded from the same ram immediately before anaesthesia (Table 1 ).

$\dagger$ Abdominal cavity temperature near internal inguinal ring.

\pm Temperatures measured in a terminal coil of the internal spermatic artery (Pl. 2, Fig. 2).

The mean temperature in the aorta at the origin of the internal spermatic arteries in seven rams was $39.6^{\circ} \mathrm{C}$. The aortic temperatures were $0.1{ }^{\circ}$ to $0.5^{\circ} \mathrm{C}$ lower than the rectal temperatures recorded simultaneously. The temperature of the blood in the internal spermatic artery where it emerges from the external inguinal ring (Level $\mathrm{A}, \mathrm{Pl}$. 2, Fig. 2) was measured in two experiments and found to be $0.4^{\circ} \mathrm{C}$ and $0.8^{\circ} \mathrm{C}$ lower than in the aorta (Table 2). The blood temperature dropped by $4.8^{\circ} \mathrm{C}$ between the aorta and the terminal coils of the artery, and by $5 \cdot 2^{\circ} \mathrm{C}$ between the aorta and the artery where it emerges from the spermatic cord onto the testis surface. The mean temperature drop from the aorta to the tissue of thirteen testes was $5 \cdot 5^{\circ} \mathrm{C}$, so that the reduction in temperature between the blood in the artery at Level $\mathrm{B}$ and the testicular tissue was $0.3^{\circ} \mathrm{C}$ (range $0.1^{\circ}$ to $0.8^{\circ} \mathrm{C}$ ). Thus, by far the greatest cooling takes place in the coiled portion in the spermatic cord although the temperature of 
the blood in the internal spermatic artery is dropping along its whole length.

The mean temperature of the subcutaneous scrotal tissue, measured over the mid-posterior surface of the testis in seven rams, was $33.0^{\circ} \mathrm{C}$. There was a mean rise of $0.4^{\circ} \mathrm{C}$ from $32.9^{\circ}$ to $33.3^{\circ} \mathrm{C}$ between the temperatures of the subcutaneous tissue and the blood in the veins on the posterior surface of the testis in four rams in which both were measured (Table 2). In passing through the pampiniform plexus to Level $A$, the temperature of the venous blood rose by a mean of $5.1^{\circ} \mathrm{C}$ in three experiments in which temperatures at Levels $\mathrm{A}$ and $\mathrm{B}$ were recorded for the same testis (Table 2).

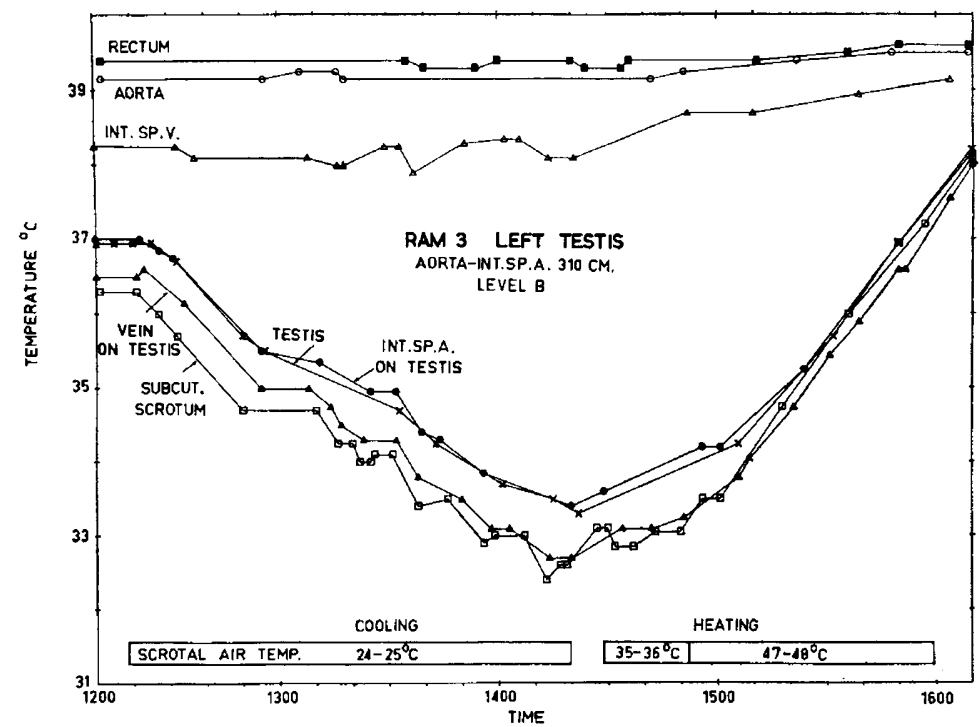

TEXT-FIG. 1. The effects of cooling and warming the scrotum on the central and testicular temperature measurements of an anaesthetized ram. The graphs of temperature in Text-figs. 1 to 3 are derived from records taken every minute; points were plotted when the temperatures changed. Cooling started at $12.09 \mathrm{hr}$ and stopped at $14.20 \mathrm{hr}$; heating from 14.29 to $16.00 \mathrm{hr}$. The length of the artery given was obtained from the Neoprene cast made after the experiment.

The temperature of the arterial blood at Level $\mathrm{A}$ in these three experiments can be estimated from the aortic blood temperature if it is assumed that the blood cooled by an average of $0 \cdot 6^{\circ} \mathrm{C}$ between these points, as in the experiments in which these temperatures were measured. The estimated fall in arterial blood temperature between Levels $\mathrm{A}$ and $\mathrm{B}$ was therefore $4.8^{\circ} \mathrm{C}$, when the equivalent rise in venous blood temperature was $5 \cdot 1^{\circ} \mathrm{C}$. It is concluded from the gradients recorded and on anatomical considerations that heat exchange between the two blood streams was occurring.

The mean temperature in the cremaster muscle recorded at its insertion into the tunica vaginalis in two experiments was $36.4^{\circ} \mathrm{C}$ (Pl. 2, Fig. 2). The values recorded were $2.2^{\circ}$ and $2.5^{\circ} \mathrm{C}$ higher than those of the blood in the artery at Level $\mathrm{B}$ in the same experiments, and $3.2^{\circ} \mathrm{C}$ higher than the venous blood at Level $\mathrm{B}$ in one. Thus it is likely that venous blood in the pampiniform plexus may exchange heat with the spermatic cord tissue as well. 


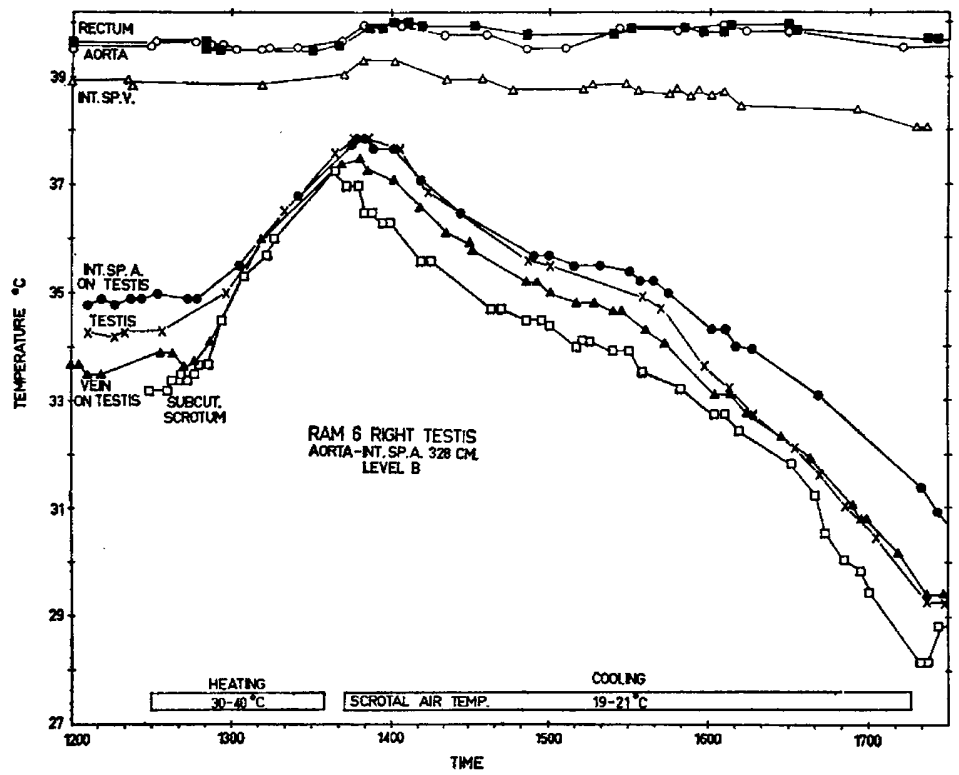

TEXT-FIG. 2. The effects of gradual cooling over a wide range on the relationships between the testicular blood and tissue temperatures. Cooling started at $13.42 \mathrm{hr}$ and was maintained at approximately $2 \cdot 4^{\circ} \mathrm{C} / \mathrm{hr}$ until $17 \cdot 16 \mathrm{hr}$.

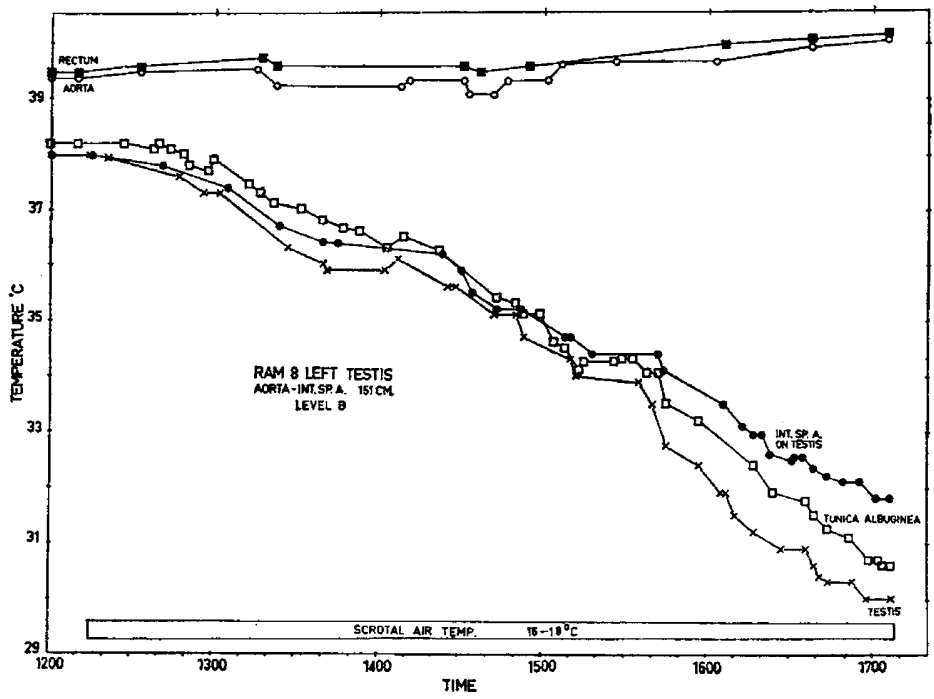

TExT-FIG. 3. To show the reversal of the temperature gradient between the blood in the internal spermatic artery at Level $B$ and the surface of the overlying tunica albuginea when the testis was cooled from $38^{\circ}$ to $30^{\circ} \mathrm{C}$. Cooling started at $12.15 \mathrm{hr}$ and was maintained at approximately $1 \cdot 7^{\circ} \mathrm{C} / \mathrm{hr}$ until $17 \cdot 07 \mathrm{hr}$. 
EFFEGTS OF GOOLING THE SGROTUM

After the values given in the previous section had been recorded, the testicular temperatures were raised to $37^{\circ}$ to $40^{\circ} \mathrm{C}$. When the temperatures were steady, the scrotum was cooled.

Testicular temperatures rapidly changed in response to cooling the scrotum; the typical sequence of changes is shown following times $12 \cdot 10 \mathrm{hr}$ in Text-fig. 1 and $13.47 \mathrm{hr}$ in Text-fig. 2. When the subcutaneous scrotal temperature

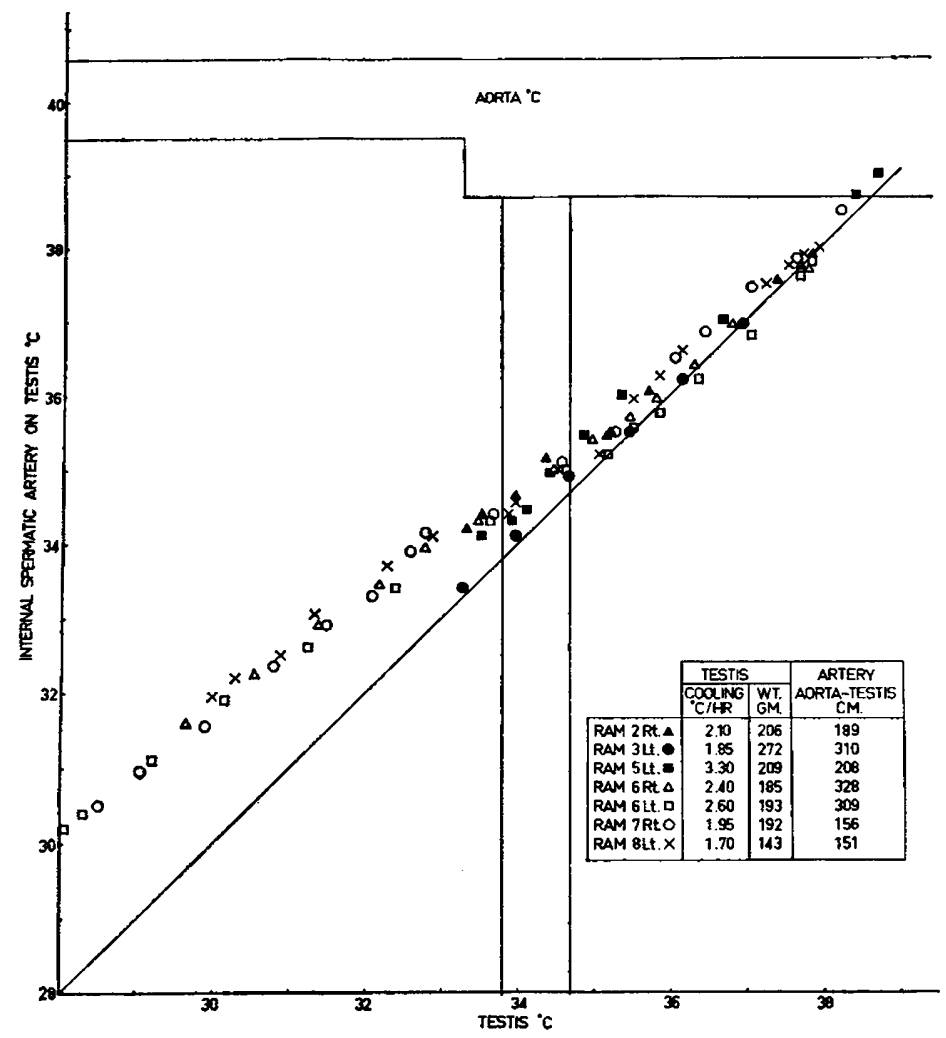

TExT-FIG. 4. The relationship during cooling of the temperature of the blood in the internal spermatic artery at Level $B$ and deep in the tissue of seven testes. Diagonal line: $45^{\circ}$ line of equal arterial blood and testicular temperatures. Horizontal lines: the limits of the aortic blood temperatures recorded in these experiments; the range is narrower below $33.3^{\circ} \mathrm{C}$ because fewer animals are involved. Vertical lines: the range of testicular temperatures measured from the same rams when conscious (Table 1 ).

started to fall, the blood in the vein on the testis cooled almost immediately; the blood in the artery at Level B then cooled within 2 min and the temperature deep in the testis fell soon after this. The testicular tissue temperature followed sharp falls of subcutaneous temperature within 3 min (Text-fig. 1). The relative positions of the testicular and scrotal temperatures during cooling shown in Text-figs. 1 and 2 were characteristic of the four experiments in which all of these temperatures were recorded (Table 2). The venous blood at Level $\mathrm{B}$ was always within $1^{\circ} \mathrm{C}$ of the scrotal subcutaneous temperature and closely followed fluctuations of the latter (Text-fig. 1). 
When testicular temperatures were higher than $37.5^{\circ} \mathrm{C}$, the difference between them and the temperature of the blood in the artery at Level $\mathrm{B}$ was less than $0 \cdot 2^{\circ} \mathrm{G}$. This difference gradually enlarged during cooling in all experiments except the one shown in Text-fig. 1. This trend was examined in Rams 6 to 8 in which four testes were cooled at approximately $2^{\circ} \mathrm{C} / \mathrm{hr}$ to $28^{\circ}$ to $30^{\circ} \mathrm{C}$. Comparisons were made when temperatures were level or falling at a steady rate. The results from two testes are shown in Text-figs. 2 and 3 , and the relationship between the temperature of the arterial blood leaving the spermatic cord and the testis are given for seven testes in Text-fig. 4. A break in the relationship occurred between $34^{\circ}$ to $35^{\circ} \mathrm{C}$ and at the lowest temperatures examined; the arterial blood was $1.6^{\circ}$ to $2.2^{\circ} \mathrm{C}$ warmer than the tissue of the testis it supplied. The relationships observed were remarkably similar despite differences in the rate of cooling, the length of artery between the aorta and Level B, and the testis weight (Table insert in Text-fig. 4).

Venous blood temperatures were recorded from only one testis cooled below $34^{\circ}$ to $35^{\circ} \mathrm{C}$ (Text-fig. 2). In this, the testis cooled sharply from $34.5^{\circ}$ to $33^{\circ} \mathrm{C}$ (15.40 to $16.06 \mathrm{hr}$ ), after which its temperature was almost identical with that of the venous blood at Level B; the rate of cooling of the scrotal subcutaneous tissues was constant during this period. The tunica albuginea over the artery at Level B, examined in one experiment (Text-fig. 3), cooled below the temperature of the arterial bloodstream when testicular temperatures fell below $34^{\circ} \mathrm{C}$; the arterial blood was $1.2^{\circ} \mathrm{C}$ warmer than the tunica albuginea at the lowest values recorded. Thus the temperature gradients recorded on the surface of the testis favoured heat loss from the arterial bloodstream to both the overlying scrotal and the underlying testicular tissues when the latter cooled below $34^{\circ}$ to $35^{\circ} \mathrm{C}$.

The testicular temperatures at which the scrotal skin started to withdraw towards the abdomen were $33.8^{\circ} \mathrm{C}$ for the left and $34.9^{\circ} \mathrm{C}$ for the right testis in Ram 7 , and $35.5^{\circ} \mathrm{C}$ and $35.9^{\circ} \mathrm{C}$, respectively, in Ram 8 .

\section{EFFECTS OF WARMING THE SCROTUM}

The scrotum was warmed at the start of all experiments and again in some experiments after cooling. Testicular temperatures responded as quickly to a rise in scrotal subcutaneous temperatures as to a fall $(14.20 \mathrm{hr}$, Text-fig. I). The scrotal and testicular temperatures converged and then rose together when the rate of rise of the scrotal subcutaneous tissue was $1^{\circ} \mathrm{C} / 10 \mathrm{~min}$ or less.

\section{TEMPERATURE CHANGES CENTRAL TO THE SPERMATIC CORD}

The rectal and aortic temperatures remained constant within $0 \cdot 5^{\circ} \mathrm{C}$ throughout all experiments except the one shown in Text-fig. 3. In this, both temperatures rose when the testicular temperature fell below $34 \cdot 5^{\circ} \mathrm{C}$. The temperature of the venous blood at Level A in five experiments (Table 2) remained steady during moderate cooling; this temperature tended to rise during warming (Tex-fif. 1). In one experiment, the venous blood at this level was $0.3^{\circ}$ to $0.6^{\circ} \mathrm{C}$ cooler than the blood in the adjacent artery when both were measured at the same time (Table 2), and both remained steady during variations of testicular temperature 
in the range $39^{\circ}$ to $34^{\circ} \mathrm{C}$. Once, however, when the testis was suddenly warmed at a rate of $1.6^{\circ} \mathrm{C} / 10 \mathrm{~min}$, the venous temperature briefly rose above the arterial temperature by $01^{\circ} \mathrm{C}$.

\section{DISGUSSION}

Harrison \& Weiner (1949) proposed, on anatomical grounds and after measurements of the temperature of the blood in the spermatic blood vessels near the external inguinal ring in seven anaesthetized animals (two dogs, two rams and three goats), that arterio-venous heat exchange would occur in the spermatic cord. While the work presented in this paper was in progress, Dahl \& Herrick (1959) reported that the blood flowing through the internal spermatic arteries of anaesthetized dogs cooled by an average of $3^{\circ} \mathrm{C}$, and concluded that countercurrent heat transference was occurring between this artery and the pampiniform plexus. The present experiments have confirmed that heat exchange occurs between the two blood streams in the spermatic cord of the ram. When testicular temperatures were about $34^{\circ} \mathrm{C}$, the blood in the internal spermatic artery where it passes on to the surface of the testis was approximately $5^{\circ} \mathrm{C}$ cooler than the blood entering the same artery from the aorta; blood leaving the pampiniform plexus was about $5^{\circ} \mathrm{C}$ warmer than the blood in the veins on the testis surface (Pl. 2, Fig. 2). Most of these remarkable changes in temperature occurred in the spermatic cord where the internal spermatic artery was in close contact with the veins of the pampiniform plexus (Pl. 1, Fig. 1). However, there was no evidence that vascular heat exchange per se could actively regulate the temperature of the testis as originally suggested by Harrison \& Weiner (1949). Indeed, vascular heat exchange only serves to cool the testis when the returning venous blood is cooler than the arterial inflow and this relationship can be maintained only if heat is being lost through the scrotum.

Certain consequences of the vascular-heat-exchange mechanism are apparent. It enables the temperature of all the testicular tissue to approach that of the inside of the scrotal skin (Tables 1 and 2). This is possible because the temperature of the venous outflow from the testis, which in turn governs the temperature of its arterial inflow, is always similar to the temperature immediately beneath the scrotum (Text-fig. 1). This must also explain the characteristic speed and fidelity with which the temperature deep in the testis followed variations in the temperature of the scrotal subcutaneous tissue in these experiments (Text-figs. 1 and 2) and in experiments on conscious rams (Moule \& Knapp, 1950; Moule \& Waites, unpublished observations).

When the scrotum of the ram is insulated to prevent heat loss, the temperature of the testis rises rapidly (Moule \& Knapp, 1950) and, in consequence, sperm production decreases or is abolished (Moore \& Oslund, 1924; Phillips \& McKenzie, 1934; Gunn, 1936; Glover, 1955). As the range of temperatures recorded from the testes of rams standing in still air in a temperate environment is $33.8^{\circ}$ to $35.4^{\circ} \mathrm{C}$ (Phillips \& McKenzie, 1934; Moule \& Knapp, 1950; Fook, Pope, Nichols \& Casida, 1957; Table 1, this paper), it is reasonable to assume that this is within the optimal range for spermatogenesis in this species. Vascular heat exchange in the spermatic cords of all the rams examined was sufficient to 
maintain the testicular temperatures within the range $39^{\circ}$ to $34^{\circ} \mathrm{C}$ and very little cooling occurred from the arteries on the testis surface. Below $34^{\circ} \mathrm{C}$, the rate of arterial cooling did not keep pace with the rate of fall of the testicular temperatures (Tex-fig. 4). The gradients recorded on the testis surface then favoured additional heat loss from the tortuous arteries beneath the tunica albuginea to both the testicular and scrotal tissues (Text-fig. 3).

The change in the rate of arterial cooling in the spermatic cord at $34^{\circ} \mathrm{C}$ may indicate that an active process intervenes at this temperature. The tunica dartos muscle started to contract in two experiments when the mean testicular temperatures were $33.9^{\circ}$ and $35.7^{\circ} \mathrm{C}$, respectively. Phillips \& McKenzie (1934) showed that the tunica dartos muscle of rams was most sensitive to temperature changes near the normal testicular temperature, which in their animals averaged $34 \cdot 9^{\circ} \mathrm{C}$. The contraction of this muscle and the consequent reduction in the volume of the scrotal sac would bring the pampiniform plexus closer to the warmer inguinal tissue. This would warm the returning venous blood and reduce the rate of heat exchange in the spermatic cord.

A direct relationship between the length of the internal spermatic artery and the temperature gradient between the body and the testis was suggested to exist between different species by Harrison \& Weiner (1949) and between individuals of the same species (bull) by Kirby \& Harrison (1954). As the testicular temperatures of Dahl \& Herrick's (1959) dogs when conscious were not given, the vascular gradients at the normal testicular temperatures of the dog and ram cannot be compared. However, there was no indication that the rectal-testicular temperature gradients recorded from conscious rams was related to the length of the internal spermatic artery (Table 1). Although the artery lengths varied between 151 and $324 \mathrm{~cm}$, the temperature gradients in all rams were very similar at the moderate air temperatures that prevailed. Also, the relationship between cooling in the artery over a wide range of testicular temperatures was the same regardless of the length of the artery involved (Text-fig. 4). No attempt has been made to exclude other factors that might limit heat loss from the artery, although the haemodynamic consequences of its length in the ram have been considered previously (Waites \& Moule, 1960).

Temperature gradients have long been known to exist in central blood vessels (Claude Bernard, 1876) and heat exchange occurs between peripheral arteries and their venae comites in human limbs (Bazett \& McGlone, 1927; Bazett, Love, Newton, Eisenberg, Day \& Forster, 1948; Bazett, 1949). Precooling of the arterial inflow to the hand serves to conserve heat which would otherwise be lost to the environment. In this respect, the testicular vessels would have the same function. In hot conditions, however, the superficial cutaneous veins of the limbs are dilated and this, together with an associated constriction of the venae comites, is thought to reduce the possibility of undesirable pre-warming of the arterial inflow (Bazett, 1949). The scrotal and testicular veins of the ram are normally quite separate, and the shunting of blood between them as a thermo-regulatory measure could not take place. Harrison \& Weiner's (1949) experiments and one experiment in this study showed that pre-warming of the testicular arterial inflow by venous blood occurred when the scrotum was rapidly heated. This further emphasizes that 
the magnitude and direction of vascular heat exchange depends upon the bodyscrotal gradient.

The anaesthesia necessarily used in these experiments would be likely to reduce the efficiency of scrotal mechanisms for heat dissipation. For this reason, the subcutaneous temperature of the scrotum has been used as the reference temperature by which the testicular temperature was changed. There is no new evidence from this investigation about scrotal thermo-regulatory mechanisms, although other work has shown that the scrotum of the ram is well endowed with cutaneous thermal receptors (Waites, 1961).

\section{AGKNOWLEDGEMENTS}

We wish to thank Mr J. K. Voglmayr for skilled assistance at every stage and Miss Y. Clarke for help during the experiments. We are also grateful to Mr D. Murray of Dural Plastics, Dural, N.S.W., for his care in enclosing the thermocouple wires in polythene.

\section{REFERENCES}

BAzETT, H. C. (1949) The regulation of body temperatures. Physiology of Heat Regulation by L. H. Newburgh, p. 147. W. B. Saunders \& Co, Philadelphia.

Bazett, H. C., Love, L., Newton, M., Eisenberg, L., Day, R. \& Forster, R. (1948) Temperaturè changes in blood flowing in arteries and veins. 7. appl. Physiol. 1, 3.

Bazett, H. C. \& McGlone, B. (1927) Temperature gradients in the tissues in man. Amer. J. Physiol. $82,415$.

Bernard, C. (1876) Legons sur la chaleur animale sur les effets de la chaleur et sur la fièvre. J. B. Baillière et fils, Paris.

DAHL, E. V. \& Herrick, J. F. (1959) A vascular mechanism for maintaining testicular temperature by counter-current exchange. Surg. Gynec. Obstet. 108, 697.

Fook, W. C., Pope, A. L., Nichols, R. E. \& Casida, L. E. (1957) The effect of variations in ambient temperature and humidity on rectal and testis temperatures of sheared and unsheared rams. 7. Anim. Sci. 16, 144.

Glover, T. D. (1955) Some effects of scrotal insulation on the semen of rams. Studies on Fertility, 7, 66.

GunN, R. M. C. (1936) Fertility in sheep. Artificial production of seminal ejaculation and the characters of the spermatozoa contained therein. Bull. Coun. sci. industr. Res. Aust. No. 94.

Harrison, R. G. (1949) The comparative anatomy of the blood supply of the mammalian testis. Proc. zool. Soc. Lond. 119, 325.

HARrison, R. G. \& WEINER, J. S. (1949) Vascular patterns of the mammalian testis and their functional significance. 7. exp. Biol. 26, 304.

KIRBy, A. \& Harrison, R. G. (1954) A comparison of the vascularization of the testis in Afrikaner and English breeds of bull. Proc. Soc. Study of Fertility, 6, 129.

MoORE, C. R. \& OsLund, R. (1924) Experiments on the sheep testis - cryptorchidism, vasectomy and scrotal insulation. Amer. J. Physiol. 67, 595.

Moule, G. R. \& KNAPP, B. (1950) Observations on intra-testicular temperatures of Merino rams. Aust. F. agric. Res. 1, 456.

Phillips, R. W. \& McKenzie, F. F. (1934) The thermo-regulatory function and mechanism of the scrotum. Res. Bull. Mo. Agric. Exp. Sta. No. 217.

Wartes, G. M. H. (1961) The polypnoea evoked by heating the scrotum of the ram. Nature, Lond. $190,172$.

WAITEs, G. M. H. \& MouLe, G. R. (1960) Blood pressure in the internal spermatic artery of the ram. F. Reprod. Fertil. 1, 223. 